\title{
Genetically modified crops: Brazilian law and overview
}

\author{
C.D. Marinho1, F.J.O. Martins², A.T. Amaral Júnior ${ }^{3}$, L.S.A. Gonçalves ${ }^{4}$, \\ O.J.A.P. dos Santos ${ }^{4}$, D.P. Alves ${ }^{1}$, B.P. Brasileiro ${ }^{1}$ and L.A. Peternelli ${ }^{1}$ \\ ${ }^{1}$ Departamento de Estatística, Universidade Federal de Viçosa, \\ Viçosa, MG, Brasil \\ ${ }^{2}$ Departamento de Administração, Universidade Federal de Viçosa, \\ Viçosa, MG, Brasil \\ ${ }^{3}$ Universidade Estadual do Norte Fluminense Darcy Ribeiro, \\ Campos dos Goytacazes, RJ, Brasil \\ ${ }^{4}$ Centro de Ciências Agrárias, Universidade Estadual de Londrina, \\ Londrina, PR, Brasil \\ Corresponding author: C.D. Marinho \\ E-mail: caillet.marinho@yahoo.com.br \\ Genet. Mol. Res. 13 (3): 5221-5240 (2014) \\ Received January 22, 2014 \\ Accepted June 10, 2014 \\ Published July 7, 2014 \\ DOI http://dx.doi.org/10.4238/2014.July.7.15
}

\begin{abstract}
In Brazil, the first genetically modified (GM) crop was released in 1998, and it is estimated that 84,78 , and $50 \%$ of crop areas containing soybean, corn, and cotton, respectively, were transgenic in 2012. This intense and rapid adoption rate confirms that the choice to use technology has been the main factor in developing national agriculture. Thus, this review focuses on understanding these dynamics in the context of farmers, trade relations, and legislation. To accomplish this goal, a survey was conducted using the database of the National Cultivar Registry and the National Service for Plant Variety Protection of the Ministry of Agriculture, Livestock and Supply [Ministério da Agricultura, Pecuária e Abastecimento (MAPA)] between 1998 and October 13, 2013. To date, 36 events have been released: five for soybeans, 18 for corn, 12 for cotton, and one for
\end{abstract}


beans. From these events, 1395 cultivars have been developed and registered: 582 for soybean, 783 for corn and 30 for cotton. Monsanto owns $73.05 \%$ of the technologies used to develop these cultivars, while the Dow AgroScience - DuPont partnership and Syngenta have 16.34 and $4.37 \%$ ownership, respectively. Thus, the provision of transgenic seeds by these companies is an oligopoly supported by legislation. Moreover, there has been a rapid replacement of conventional crops by GM crops, whose technologies belong almost exclusively to four multinational companies, with the major ownership by Monsanto. These results reflect a warning to the government of the increased dependence on multinational corporations for key agricultural commodities.

Key words: Transgenic crops; Brazilian biotechnology; Property rights; Adoption of transgenic

\section{INTRODUCTION}

In recent years, the use and release of genetically modified (GM) organisms (GMOs) have been matter of intense public interest. The worldwide planting of GMOs reached 170.3 million hectares in 2012. Soybean, corn, cotton and canola fields totaled an area of 148.1 million hectares worldwide, with proportions of $49,32,14$, and $5 \%$, respectively (Brookes and Barfoot, 2010). That same year, other GM crops were planted on smaller areas in the U.S. (papaya, pumpkin, beet, and alfalfa), Canada (beet) and China (papaya). Of the areas planted with soybean, corn, cotton, and canola, approximately $72,28,56$, and $23 \%$, respectively, were cultivated with GMOs worldwide.

Among the 28 countries producing GMOs, Brazil is the second largest in crop acreage, with 36.6 million hectares, surpassed only by the U.S. with 69.5 million hectares (Table 1). This position has been maintained since 2009, when Brazil experienced a $35.40 \%$ increase in the area planted with GMOs, thus becoming the country with the highest rate of adoption (James, 2009). It was estimated that 83.4\% of soybean fields in Brazil's 2012/2013 harvest were planted with GMOs; for corn, the value was $77.7 \%$ (first and second harvests), and GMO cotton reached $49.4 \%$ of the total (Céleres, 2013).

\begin{tabular}{|c|c|c|c|c|}
\hline \multirow[t]{2}{*}{ Country } & \multicolumn{3}{|c|}{ Area (million ha) } & \multirow[t]{2}{*}{ GM crop } \\
\hline & 2012 & 2011 & 2010 & \\
\hline USA & 69.5 & 69 & 66.8 & Soybean, maize, cotton, canola, squash, papaya, alfafa, and sugar beet \\
\hline Brazil & 36.6 & 30.3 & 25.4 & Soybean, maize and cotton \\
\hline Argentina & 23.9 & 23.7 & 22.9 & Soybean, maize and cotton \\
\hline Canada & 11.6 & 10.4 & 8.8 & Canola, maize, soybean, and sugar beet \\
\hline India & 10.8 & 10.6 & 9.4 & Cotton \\
\hline China & 4 & 3.9 & 3.5 & Cotton, tomato, poplar, petunia, papaya, and sweet pepper \\
\hline Total & 156.4 & 147.9 & 136.8 & - \\
\hline
\end{tabular}

Based on James C (2011, 2012). 
The intrinsic characteristics of the transgenics approved for sale in Brazil are herbicide tolerance and/or resistance to insects and viruses in the case of beans. It should be noted that among the transgenic crops for the 2013/2014 harvest in Brazil, 63.1\% of GMOs are expected to exhibit herbicide tolerance, $16.5 \%$ insect resistance, and $20.4 \%$ both features (Céleres, 2013).

There has been an intense and rapid adoption of GMOs by producers, resulting in considerable economic gains. Thus, small- and medium-scale farmers are concerned about the sharp increase in the use of GMOs in commodity markets, where multinational companies dominate trade. Biotechnology studies, especially those based on genetic engineering, are expensive and take a long time. Therefore, such studies are more viable for companies with large capital and, obviously, advanced technology (Araújo, 2010; Potrykus, 2010). Since multinational companies promote research and develop new technologies, they will obviously occupy greater space in the Brazilian market, consequently reducing the space occupied by domestic companies.

Therefore, a need arises to better understand these dynamics in the context of farmers, trade relations and legislation. This study was developed to identify the commercial releases of GMOs in Brazil, their features, the genetic transformation events used and the companies responsible for developing them. The companies were classified as public or private and subdivided into multinational, foreign, and domestic companies. This study also aimed to investigate the laws governing activities related to these organisms and the intellectual property adopted in this field.

\section{MATERIAL AND METHODS}

Data were obtained from the database of Registro Nacional de Cultivares (RNC) and Serviço Nacional de Proteção de Cultivares (SNPC), called CultivarWeb, which is available in real time on Ministério da Agricultura, Pecuária e Abastecimento (MAPA) website (http://www.agricultura.gov.br/). The survey was conducted in the period of 1998 to October 13, 2013.

The survey pooled the records and protections according to the nature of the institutions, which were separated into the following categories: private institutions (subsequently subdivided into multinational, foreign and domestic institutions) and public institutions. Companies that have a branch in Brazil and headquarters in another country but do not operate in several countries, as multinational companies do, were classified as foreign. The data were tabulated and analyzed in Microsoft Office Excel 2010, and they are presented using descriptive statistics.

To select the species that comprised this study (soybeans, corn, cotton and beans), existing commercial approvals in the country, conferred by Conselho Técnico Nacional de Biossegurança (CTNBio), were taken into consideration. All technical information on commercial releases was based on the technical advice of the board.

\section{RESULTS}

\section{Laws and legal issues}

In March 2005, the biosafety law (Law number 11.105/05) was modified to establish 
safety rules and mechanisms for monitoring activities that involve GMOs and their derivatives. It also gives CTNBio the authority to control the activities related to GMOs. According to this law, MAPA is in charge of registering and monitoring the commercial release of GMOs and their derivatives for animal use, in agriculture, cattle raising, agroindustry and related areas, according to the technical recommendations of the CTNBio (Brasil, 2005).

After an evaluation by the CTNBio and technical recommendation for the release of a certain GMO, MAPA is in charge of registering the cultivars already approved and monitoring the use of these materials. Accordingly, MAPA coordinates SNPC and RNC, which are in charge of receiving the requests for protection and registration of new cultivars, including those genetically modified.

Cultivar protection is ruled by the Law $9.456 / 97$ and Decree number 2.366/97. This law basically grants a certificate that recognizes the intellectual property of a new plant variety resulting from the work of plant breeders. It aims to protect scientific knowledge, which allows individuals and organizations that carry out plant breeding to receive royalties for the use of new varieties marketed, and to refund them for the investments made, encouraging them to continue the research process (Teramoto and Teixeira, 2008; Marinho et al., 2011). Therefore, SNPC is in charge of evaluating the requests and ensuring the intellectual property rights of the producers of new phylogenetic combinations, in the form of distinct, homogenous and stable cultivars (Carvalho et al., 2009).

The national registration of cultivars, through $\mathrm{RNC}$, is ruled by the Law of Seeds number 10.711/03, which gives cultivar producers permission to produce, process and sell seeds and seedlings in the whole country, establishing mechanisms to record and organize detailed information about the traits of the cultivars registered (Carvalho et al., 2009).

Cultivar protection is usually confused with cultivar registration, but there is a clear distinction between the two procedures. The protection, granted by SNPC, guarantees that producers will enjoy the property rights of the cultivar developed and will receive royalties for the sale of the material protected. Registration, on the other hand, is granted by the recording of the cultivar in the RNC, which is a mandatory request for the production, processing and sale of seeds and seedlings of any cultivar, not only for the protected cultivars. Therefore, protection establishes the ownership of cultivars, while registration enables cultivars to be marketed (Teramoto and Teixeira, 2008).

Another code applied to this study is the Law number 9.279/96 (Industrial Property Law), which grants a patent to the invention that meets the following requirements: novelty, invention activity and industrial application. This law created an exception by prohibiting the patent of living beings. The patent grants to its owner the right to prevent third parties from making, using, offering for sale, selling, or importing, without consent, the process or product directly achieved by the patented process. Therefore, the process of insertion of a gene or genetically modified material in a plant results in products and seeds, and in this case, it is ruled by the norms of Industrial Property, which grants to patent owners the right to receive royalties for their invention.

In both cases, either patent or protection of cultivars, the right to receive royalties is granted to owners. This tax is established by the market, according to consumers' acceptance of the strategies of companies, without any participation of government or farmers, since the Law does not determine maximum levels for taxation.

There are some significant differences between the Law of Industrial Property (LIP) and the Law of Cultivar Protection (LCP). Patents are valid for 20 years from the date of the 
deposit of patent request. The certificate of protection, on the other hand, is in force from the date when the Temporary Certificate of Protection is granted, and lasts 15 years, except for vines, fruit trees, forest trees and ornamental trees, including in each case, their rootstock, for which the duration is 18 years. After the validity of property rights, the invented cultivar becomes public domain and no right will affect its free use.

Another important difference is that LCP, in opposition to LIP, guarantees the "rights of farmers", assuring that they can reserve part of their harvest, within their properties, for future sowing without the need for previous authorization or any payment to those who developed the seeds. In other words, farmers can keep and reproduce their seeds without having to pay for the purchase of new seeds for cultivation in the next growing season. LCP also allows small farmers to multiply seeds for donation or exchange, exclusively with other small farmers, as part of programs for funding or supporting small farmers, conducted by public agencies or NGOs authorized by government. The Law also recognizes "breeders' exemption", admitting the free use of the protected cultivar for research, as a source of variation. It means that farmers can use the improved seeds to develop other seed variations, continuing the breeding process (Brasil, 1997).

Therefore, it can be observed that intellectual property of plant breeding is under the effects of the Law of Cultivar Protection, which is the only form of plant protection, including for GM products. However, a gap is observed when the product of the genetic engineering process becomes patentable. In this case, GM seeds are protected by the Law of Industrial Property. It is possible to see that GMOs can be protected twice (although Brazil is a supporter of the 1978 UPOV Convention, which prohibits such practice), since they can be patented because they are fruits of a biotechnological process and protected when new cultivars are developed from a previously patented procedure.

Therefore, this legislation has been questioned. Patents are very strict in relation to the rights of the owners and do not allow any inventions to be released without the consent of the inventors. However, the Law of Protection guarantees the rights of farmers and breeders. Thus, if a cultivar were both patented and protected, the Law of Protection would break the rigidity of the patent, since producers could keep seeds for future planting seasons, which in fact does not occur, because one of the main clauses in the contracts for the release of patented technology is prohibiting farmers to keep seeds to be used in the following harvest.

\section{Events approved for sale}

Table 2 shows information on the genetic transformation events released to date, including the inserted genes, characteristics acquired and companies responsible for patents.

In Brazil, CTNBio had approved 36 events at the time of this study: five for soybeans, 18 for corn, 12 for cotton and one for beans. The first approval occurred in 1998 for "Roundup Ready" soybeans from Monsanto. This product was later suspended and re-released in Brazil in 2005. Since then, there have been releases of GM cotton in 2005, three releases for GM corn in 2007 and five releases of GMOs in 2008, including three for corn and two for cotton. In 2009, there were nine GMO releases: one for soybeans, five for corn and three for cotton. In 2010, eight new events were approved: three for soybeans, four for corn and one for cotton. Over the subsequent two years (2011 and 2012), nine new GMO events were released: three for corn, five for cotton and one for beans. It is undeniable that there was a rapid increase in GMOs over recent years. Of the 36 GMOs released by CTNBio since 1998, 31 were released in the past five years (Table 2). 


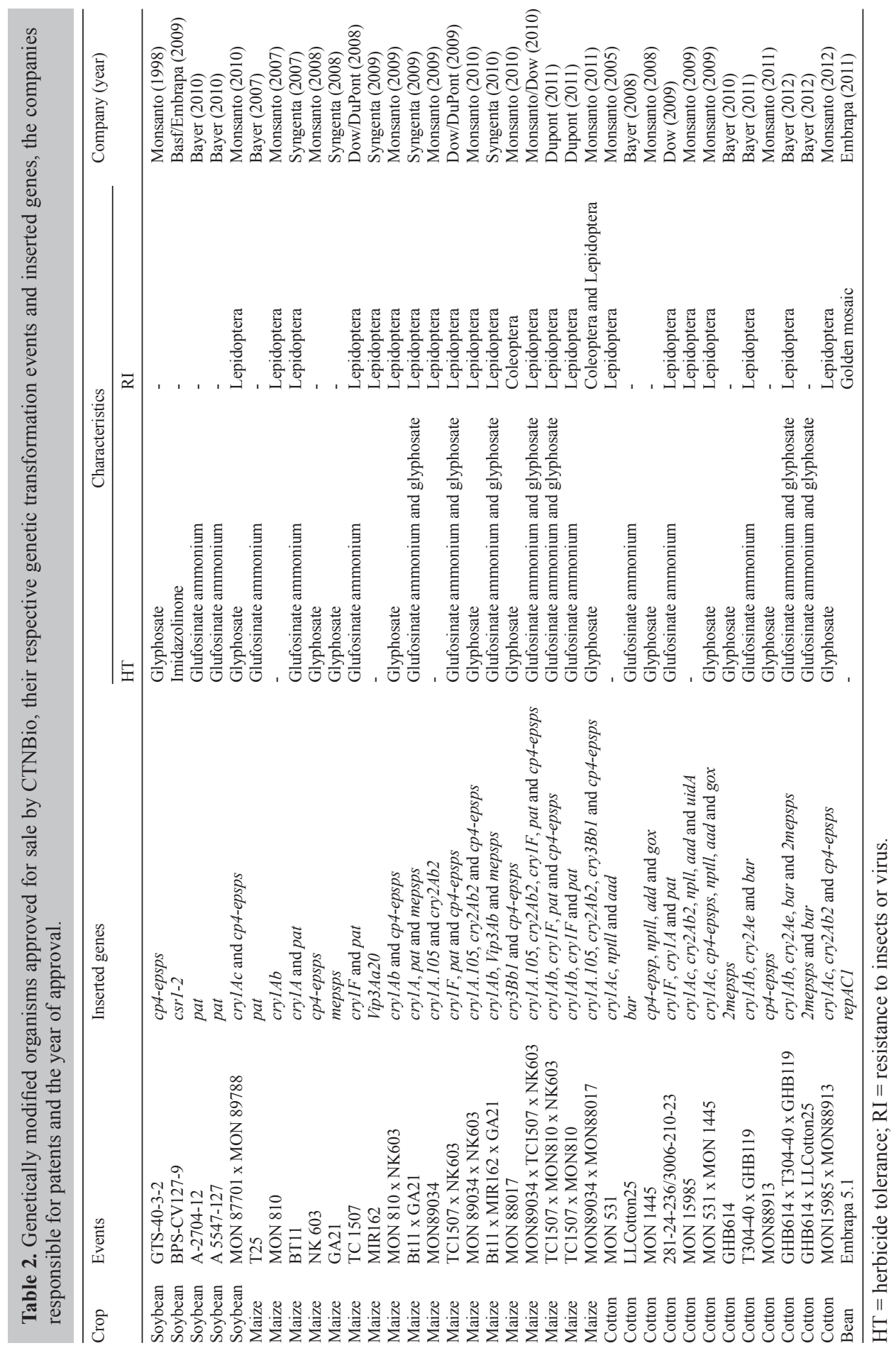


Only one transgenic event (Embrapa 5.1) was developed exclusively by a Brazilian institution (Empresa Brasileira de Pesquisa Agropecuária - Embrapa), and one event (BPSCV127 -9) was derived from a partnership between Embrapa and BASF (Table 2). This situation shows that Brazil depends on technologies produced by multinational corporations. This effect is evident in Table 2, which shows that the other transgenic events were developed by multinational companies, particularly Monsanto (15), followed by Monsanto partnering with Dow AgroSciences (1), Syngenta (5) and Bayer (8), and DuPont partnering with Dow AgroSciences (2), DuPont (2) and Dow AgroSciences (1). Thus, only six multinational companies dominate this biotechnology sector. Monsanto exclusively owns $41.67 \%$ of the relevant patents, followed by Bayer (22.22\%) and Syngenta (13.89\%). Therefore, these three companies hold $77.78 \%$ of the existing patents on transgenic plants in Brazil.

\section{GM soybean}

There are five released transgenic soybean events. The first release was for event GTS 40-3-2, which resulted in Roundup Ready soybean from Monsanto. This event involved the insertion of the cp4 epsps gene from the soil bacterium Agrobacterium tumefaciens, leading to tolerance to glyphosate, which is the main ingredient in the herbicide Roundup owned by Monsanto (CTNBio, 2013).

In 2009, then came event BPS-CV127-9 from Cultivance Soybeans from BASF in partnership with Embrapa. This event involved the insertion of the csrl-2 gene from Arabidopsis thaliana, allowing tolerance to imidazolinone herbicides (CTNBio, 2013). Shortly thereafter, Liberty Link soybeans (LL soybean) were developed by Bayer as event A2704-12. This event resulted from the insertion of the pat gene, which is a modified version of a gene isolated from the natural soil bacterium Streptomyces viridochromogenes, allowing tolerance to glufosinate ammonium (CTNBio, 2013). Another event, A 5547-127, was developed by Bayer and is also known as Liberty Link soybean. It has the same characteristics as A2704-12, but it contains only one copy of the pat gene instead of two copies as in event A2704-12 (CTNBio, 2013).

MON87701 x MON89788 soybean was derived by crossing using classical breeding techniques. In this case, GM soybean progenitors were used: MON87701 exhibits insect resistance, and MON89788 exhibits glyphosate tolerance. The MON87701 event has the crylAc gene derived from Bacillus thuringiensis, and the MON89788 event contains the cp4 epsps gene derived from Agrobacterium sp, which codes for the CP4 EPSPS protein. This protein has insecticidal activity, thereby ensuring resistance to lepidopteran pests, which are common in tropical and subtropical regions, especially Anticarsia gemmatalis, the velvetbean caterpillar moth, and Pseudoplusia includens, the soybean looper. Crocidosema aporema, the bean shoot moth, and Rachiplusia nu, the sunflower looper, are secondary targets that are also important in South America. The cp 4 epsps gene ensures glyphosate tolerance. The goal of this event combination was to obtain soybeans with pest resistance and tolerance to glyphosate (CTNBio, 2013).

\section{GM corn}

The first approval for corn was in 2007 for Liberty Link from Bayer, event T25. This variety contains the pat gene, as does Liberty Link soybeans, and thus shows tolerance to the herbicide glufosinate ammonium (CTNBio, 2013). In the same year, event MON810 from 
Monsanto was approved, resulting in "Guardian" corn containing the $c r y l A b$ gene from $B a$ cillus thuringiensis subsp. Kurstaki. This gene encodes the CrylAb protein, which is toxic to lepidopteran pests (fall armyworm, Spodoptera frugiperda; corn earworm, Helicoverpa zea; and sugarcane borer, Diatraea saccharalis) (CTNBio, 2013). Soon thereafter, Bt11 corn was developed by Syngenta, which contains the cry $1 A$ and pat genes. This corn expresses the $\operatorname{cry} l A(b)$ gene, which is a fusion of the crylA and pat genes from the bacteria Bacillus thuringiensis var. kurstaki and Streptomyces viridochromogenes, respectively. Thus, the plant exhibits pest resistance and tolerance to glufosinate ammonium. The following pests are affected: fall armyworm, corn earworm and black cutworm (Agrotis ipsilon) (CTNBio, 2013).

Three more requests were granted in 2008, starting with Roundup Ready 2 corn from Monsanto, event NK603, which shows tolerance to glyphosate (CTNBio, 2013). Shortly thereafter, two more approvals occurred. The first approval was for GA21 corn from Syngenta, which is tolerant to glyphosate and was developed from the event GA21 by the insertion of the mepsps gene (modified from the conventional corn epsps gene) (CTNBio, 2013). The second approval was for "Herculex" corn, which was developed by a partnership between Dow AgroSciences and DuPont. The transformation event used to produce this corn is called TC1507, and it involved the introduction of the $c r y 1 F$ and pat genes; the former is from the bacterium Bacillus thuringiensis var. aizawai and the latter from Streptomyces viridochromogenes. The cry $1 F$ gene confers resistance to the following lepidopteran pests: fall armyworm, corn earworm and sugarcane borer, and as mentioned, the pat gene confers tolerance to glufosinate ammonium (CTNBio, 2013).

There were five releases in 2009 for corn. The first release was for "MIR162" corn, which was obtained from event MIR162 and includes the Vip3Aa20 gene from Bacillus thuriengiensis, which ensures resistance to fall armyworm, corn earworm and sugarcane borer (CTNBio, 2013). Monsanto also released a "pyramid" corn called MON810 x NK603 from a cross between NK603 with MON810, which resulted in corn with glyphosate tolerance and resistance to lepidopteran pests (CTNBio, 2013). There was also approval of another pyramid corn owned by Syngenta called "Bt11 x GA21" corn, which was obtained by classical crossing between GM lines containing the Bt11 and GA21 events in isolation. This cross resulted in the combination of the features of the parent lines (resistance to lepidopterans and tolerance to glyphosate and glufosinate ammonium) (CTNBio, 2013).

"MON89034" corn was then approved. This corn contains the cry1A.105 and cry2Ab2 genes derived from the bacterium Bacillus thuringiensis, which confer resistance to the fall armyworm, corn earworm, sugarcane borer and Ostrinia species such as the European corn borer and the Asian corn borer (CTNBio, 2013). Dow AgroScience obtained approval in 2009 in partnership with DuPont for a pyramid corn called "TC1507 x NK603" corn, which was produced by a cross between GM lines containing the TC1507 and NK603 events. This cross conferred tolerance to glufosinate ammonium and glyphosate, in addition to resistance to lepidopterans (CTNBio, 2013).

The first GMO approved in 2010 was "MON89034 x NK603" corn. This variety resulted from the crossing of parental GM corn exhibiting insect resistance through the MON89034 event, which enables tolerance to glyphosate, and the NK603 event, which belongs to Monsanto (CTNBio, 2013). Next came "Bt11 x MIR162xGA21" corn from Syngenta, with the combination of the abovementioned events (CTNBio, 2013). The "MON88017" corn (event 88017) from Monsanto also received a favorable ruling. This genotype includes the cry $3 B b 1$ and cp4 epsps genes; the former is derived from Bacillus thuringiensis and the latter from 
Agrobacterium sp. The cry $3 \mathrm{Bb} 1$ gene is responsible for resistance to the larvae of pests from the genus Diabrotica, and as noted, the cp 4 epsps gene confers glyphosate tolerance (CTNBio, 2013). Finally, another pyramid procedure yielded the "MON89034 x TC1507 x NK603" corn owned by Monsanto and Dow AgroScience, which exhibits tolerance to glyphosate and glufosinate ammonium in addition to resistance to lepidopterans (CTNBio, 2013).

The three GMOs approved in 2011 were obtained by pyramidation of previously released events, namely the TC1507 x MON810 x NK603, TC1507 x MON810 and MON89034 $\mathrm{x}$ MON88017 events. It should be noted that the MON89034 x MON88017 event differs from the other events for corn because it combines resistance to insects of the orders Lepidoptera and Coleoptera in addition to glyphosate tolerance. This event was patented by Monsanto, and the other two by DuPont (CTNBio, 2013).

\section{GM cotton}

The first transgenic cotton was "Bollgard" from Monsanto (event MON 531), which was released in 2005. This genotype contains the $c r y l A c$ gene, which confers insect resistance and was derived from the bacterium Bacillus thuringiensis var. kurstaki. This GMO is resistant to major pests of the order Lepidoptera that affect the cotton crop in Brazil, such as cotton leafworm (Alabama argillacea), pink bollworm (Pectinophora gossypiella) and tobacco budworm (Heliothis virescens) (CTNBio, 2013).

In 2008, Bayer developed Liberty Link cotton (event LLCotton25), which exhibits tolerance to glufosinate ammonium, conferred by the bar gene derived from Streptomyces hygroscopicus (CTNBio, 2013). In the same year, Monsanto developed Roundup Ready cotton (event MON 1445), which exhibits glyphosate tolerance due to the cp4 epsp gene (CTNBio, 2013). In 2009, Dow AgroScience released "WideStrike" cotton (event "281-24-236/3006210-23"), which contains the cry $1 F$, cry $1 A$ and pat genes. The former two genes were obtained from Bacillus thuringiensis var. aizawai strain PS811 and Bacillus thuringiensis var. kurstaki strain HD73, and they confer resistance to the following pests: tobacco budworm, corn earworm, fall armyworm, cotton leafworm, pink bollworm, beet armyworm (Spodoptera exigua), southern armyworm (Spodoptera eridania), soybean looper and cabbage looper (Trichoplusia ni). The pat gene is a synthetic version of the natural pat gene derived from Streptomyces viridochromogenes and allows tolerance to glufosinate ammonium (CTNBio, 2013).

Also in 2009, Monsanto launched two genotypes of GM cotton: "Bollgard II" (event "MON15985") and "MON531 x MON1445" (event "MON531 x MON1445"). Bollgard II is resistant to pests such as cotton leafworm, tobacco budworm, pink bollworm and fall armyworm. These forms of resistance were made possible by the insertion of the cry $2 A b 2$ and crylAc genes from Bacillus thuringiensis var. kurstaki (CTNBio, 2013). In "MON531 x MON1445", there is a combination of events for insect resistance and glyphosate tolerance (CTNBio, 2013).

Later, in 2010, Bayer produced another genotype of GM cotton called "GlyTol" (event "GHB614"), which contains the 2mepsps gene (a modified corn epsps gene) to confer tolerance to glyphosate (CTNBio, 2013). The following year (2011), the same company obtained approval for cotton called "TwinLink" (event T304-40xGHB119), which resulted from a cross of the parental GM cotton varieties T304-40 and GHB119. This event resulted in the inclusion of the previously described bar gene, which confers glufosinate ammonium tolerance, and 
the crylAb and cry $2 A e$ genes derived from the bacterium Bacillus thuringiensis. The latter two genes encode, respectively, the Cry1 Ab and Cry2Ae proteins, which confer resistance to insects such as cotton leafworm, corn earworm, tobacco budworm, armyworm (Spodoptera spp), pink bollworm and soybean looper.

The MON88913 event from Monsanto was also released in 2011. This GMO exhibits greater glyphosate tolerance than does "MON1445" cotton due to improved promoter sequences that regulate the expression of the cp4 epsps gene (CTNBio, 2013).

Bayer developed two transgenic cotton events in 2012 (events GHB614 x T304-40 x GHB119 and GHB614 x LLCotton25). The former event is called "GlyTol x Twinlink" cotton and was developed by crossing individuals containing the events T304-40 and GHB119 ("TwinLink") with individuals derived from event GHB614 ("GlyTol"). This cross resulted in the GlyTol x TwinLink combination (GHB614 x T304-40 x GHB119), which contains the following genes: 2 mepsps, which confers tolerance to glyphosate; cryl $A b$ and cry $2 A e$, which confer insect resistance (described above); and bar, which confers glufosinate ammonium tolerance. The latter event is called GlyTol x LibertyLink, and it was obtained by crossing the GM cotton varieties "GHB614" and "LLCotton25", combining tolerance to glufosinate ammonium and glyphosate (CTNBio, 2013).

Monsanto also developed a cotton variety in 2012 by pyramidation of previously released events ("MON15985 x MON88913 cotton). This GM cotton combines resistance to some lepidopteran insects and glyphosate tolerance (CTNBio, 2013).

\section{GM beans}

The only transgenic event developed exclusively by a Brazilian institution is event Embrapa 5.1, which belongs to Embrapa Rice and Beans and Embrapa Genetic Resources and Biotechnology. This event was developed using RNA interference (RNAi), and it is highly resistant to bean golden mosaic virus (BGMV) (CTNBio, 2013). A chimeric gene was delivered by a gene gun for the expression of RNA containing a fragment of the rep gene (AC1) of BGMV, which was positioned in the sense and antisense orientations (separated by an intron). This RNA forms a hairpin of double-stranded RNA (dsRNA) sequences originated from small fragments of RNA (siRNAs) that block the expression of the viral rep gene. Thus, viral replication is impaired by the lack of rep gene expression, and the bean plants thereby become resistant to the virus (CTNBio, 2013).

\section{GM crops}

When CTNBio approves a commercial application for a GMO, it also releases all progeny of the transformation. These plants are derived from crossing non-transgenic lines and populations with lines carrying the event. MAPA is responsible for registering and inspecting all GM crops derived from transformation events released by CTNBio and approving them for production and sale.

Four GM plant species have been released for sale in Brazil (Glycine max, Zea mays, Gossypium hirsutum and Phaseolus vulgaris). For soybean, 582 varieties are registered, and 313 are protected; 298 are simultaneously registered and protected. All 783 varieties of GM corn are only registered. GM cotton has 30 varieties registered, and 15 are protected, includ- 
ing 12 that are simultaneously protected and registered. There is still no GM bean cultivar registered for sale with MAPA.

Table 3 shows the existing registered GM cultivars according to the genetic transformation events used to obtain them. For corn, nine different events were used to produce the 783 registered cultivars. Of this total, 53.26\% contain Monsanto technology, 29.12\% are from Dow AgroSciences in partnership with DuPont, 7.79\% are from Syngenta, 6.39\% are from DuPont and 3.44\% are from Dow AgroSciences in partnership with Monsanto. Therefore, all corn varieties registered with MAPA resulted from technology belonging to only four multinational corporations: Monsanto, Dow AgroSciences, DuPont, and Syngenta.

\begin{tabular}{|c|c|c|c|c|c|}
\hline & Event & No. of cultivars & Company & Total/Company & $\%$ \\
\hline \multirow[t]{18}{*}{ Maize } & MON810 & 122 & Monsanto & 417 & 53.26 \\
\hline & MON88017 & 2 & Monsanto & & \\
\hline & NK603 & 105 & Monsanto & & \\
\hline & MON810 x NK603 & 36 & Monsanto & & \\
\hline & MON89034 & 100 & Monsanto & & \\
\hline & MON89034 x NK603 & 43 & Monsanto & & \\
\hline & MON89034 x MON88017 & 9 & Monsanto & & \\
\hline & Bt11 & 29 & Syngenta & 61 & 7.79 \\
\hline & GA21 & 3 & Syngenta & & \\
\hline & MIR162 & 13 & Syngenta & & \\
\hline & Bt11 x GA21 & 10 & Syngenta & & \\
\hline & Bt11 x MIR 162 x GA21 & 6 & Syngenta & & \\
\hline & TC1507 x MON810 & 25 & DuPont & 50 & 6.39 \\
\hline & TC1507 x MON810 x NK603 & 25 & DuPont & & \\
\hline & TC1507 & 160 & Dow/DuPont & 228 & 29.12 \\
\hline & TC1507 x NK603 & 68 & Dow/DuPont & & \\
\hline & MON89034 x TC1507 x NK603 & 27 & Dow/Monsanto & 27 & 3.44 \\
\hline & TOTAL & & & 783 & 100 \\
\hline \multirow{9}{*}{ Cotton } & MON1445 & 2 & Monsanto & 23 & 76.67 \\
\hline & MON531 & 3 & Monsanto & & \\
\hline & MON531 x MON1445 & 4 & Monsanto & & \\
\hline & MON15985 x MON88913 & 8 & Monsanto & & \\
\hline & MON88913 & 6 & Monsanto & & \\
\hline & LLCotton 25 & 3 & Bayer & 5 & 16.67 \\
\hline & GHB614 x LLCotton25 & 2 & Bayer & & \\
\hline & $281-24-236 / 3006-210-23$ & 2 & Dow & 2 & 6.67 \\
\hline & TOTAL & & & 30 & 100 \\
\hline \multirow{4}{*}{ Soybean } & GTS-40-3-2 & 503 & Monsanto & 579 & 99.48 \\
\hline & MON8771 x MON89788 & 76 & Monsanto & & \\
\hline & BPS-CV127-9 & 3 & Basf/Embrapa & 3 & 0.52 \\
\hline & TOTAL & & & 582 & 100 \\
\hline
\end{tabular}

Table 3 also shows that five genetic transformation events were used for the 30 registered varieties of GM cotton, of which 23 used Monsanto technology, five were from Bayer and two were from Dow AgroSciences. Thus, all existing GM cotton varieties contain technology from only three multinational corporations: Monsanto, Bayer, and Dow AgroSciences.

A more interesting point is that 579 of the 582 varieties of GM soybeans registered with MAPA are owned by Monsanto; 503 are derived from Roundup Ready technology, and 76 are from "RR2 PRO" technology. Both technologies provide tolerance to glyphosate, and the latter adds insect resistance. Thus, only three GM soybean cultivars have tolerance to imidazoline herbicides (Table 3). 
Table 4 shows all GM crops organized by the company that owns the technology employed. There are 1395 GM varieties certified by MAPA, and only six multinational corporations plus Embrapa (public institution) are responsible for the technologies adopted. Note also that Monsanto owns the processes used in $73.05 \%$ of these varieties, demonstrating the dominance of this corporation in this sector.

$\begin{aligned} & \text { Table 4. Total number of genetically modified crops organized by the company responsible for the technology } \\
& \text { used to obtain them. }\end{aligned}$
\begin{tabular}{lrr}
\hline Responsible company & Total No. (maize, soybean, and cotton) & $\%$ \\
\hline Monsanto & 1019 & 73.05 \\
Dow/DuPont & 228 & 16.34 \\
Syngenta & 61 & 4.37 \\
DuPont & 50 & 3.58 \\
Dow/Monsanto & 27 & 1.94 \\
Bayer & 5 & 0.36 \\
BASF/EMBRAPA & 3 & 0.22 \\
Dow Agrosciences & 2 & 0.14 \\
Total & 1395 & 100 \\
\hline
\end{tabular}

It is important to highlight that $85.95 \%$ of the existing GM corn varieties are resistant to lepidopterans, and this feature is exclusive (no combination) in $30.01 \%$ of the varieties. Only $11(1.40 \%)$ varieties exhibit resistance to beetles, of which 9 are also resistant to lepidopterans; all 11 are simultaneously tolerant to glyphosate. Seventy percent (548) of the varieties exhibit herbicide tolerance, and this feature is exclusive in only $13.79 \%$ of the varieties. Moreover, 198 (25.29\%) varieties express tolerance to glyphosate; 189 (24.14\%) are tolerant to glufosinate ammonium, and $17.37 \%$ are tolerant to both herbicides. Investigating the combination of features derived from modifying events reveals that $56.19 \%$ of the varieties simultaneously exhibit herbicide tolerance and insect resistance, and $31.80 \%$ of corn varieties come from pyramid events.

For cotton, $46.67 \%$ of the GM varieties were developed through pyramidation, and $56.67 \%$ of the varieties feature resistance to lepidopterans; this feature is exclusive in $10.00 \%$ of the varieties. Ninety percent of the varieties show tolerance to herbicides. Of those, $66.67 \%$ are tolerant to glyphosate, $16.67 \%$ are tolerant to glufosinate ammonium and $6.66 \%$ are tolerant to both of these compounds. Finally, $46.67 \%$ of the varieties offer both herbicide tolerance and insect resistance.

In soybeans, all varieties exhibit herbicide tolerance; $99.48 \%$ show tolerance to glyphosate, and only three GM soybean varieties are tolerant to imidazolinone herbicides. There are also 76 varieties $(13.06 \%)$ with combined resistance to lepidopteran insects and glyphosate tolerance.

Of the three crops and their 1395 existing GM varieties, 797 (57.13\%) are tolerant to glyphosate, $219(15.70 \%)$ are tolerant to glufosinate ammonium, $138(9.89 \%)$ exhibit both features, and three $(0.22 \%)$ show imidazolinone tolerance. Thus, $82.94 \%(1157)$ of the varieties feature herbicide tolerance. Therefore, multinational corporations control the sale of these products because herbicides are acquired with the seeds (Munro, 2003). Furthermore, Monsanto again stands to benefit the most because glyphosate is the main active ingredient in Roundup, which leads in sales and is owned by Monsanto. 


\section{Protections}

In total, 313 GM soybean varieties are protected by MAPA: 255 (81.47\%) were developed by private institutions (two of those varieties are represented by individuals), and only 58 $(18.53 \%)$ were developed by public institutions. There are 15 protected GM cotton varieties: 11 belong to private companies, and 4 belong to public institutions. There are currently no protected GM corn varieties (Figure 1).
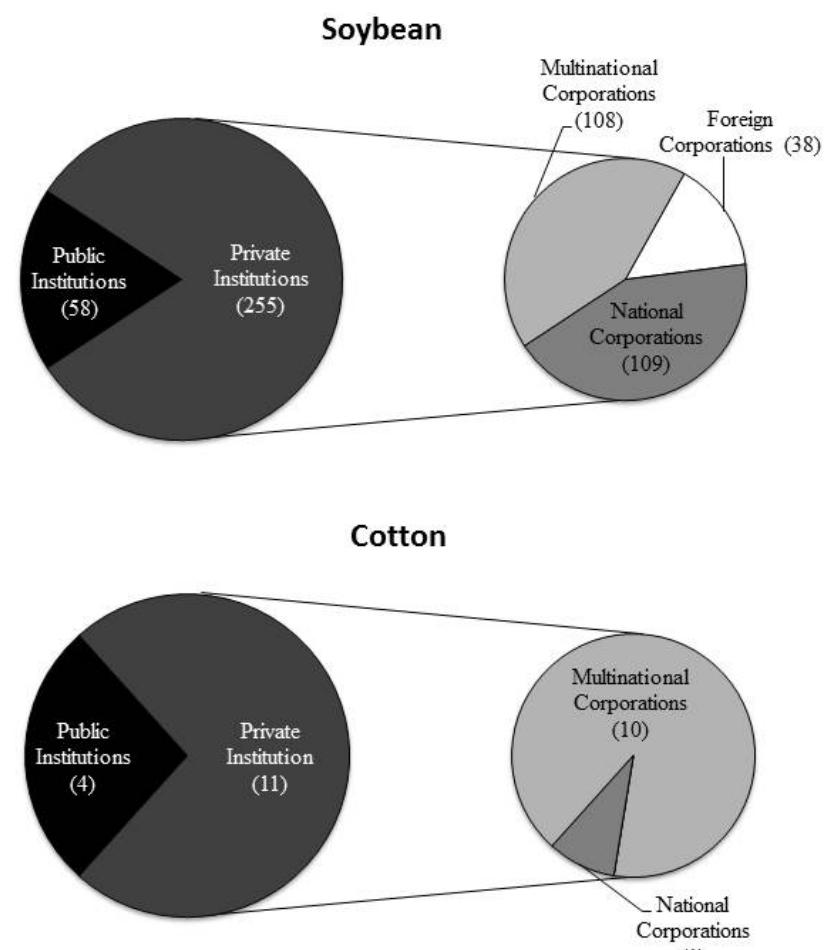

(1)

Figure 1. Number of protections for transgenic crops of soybeans, cotton and corn according to the nature of the responsible institutions.

Private institutions can be classified into domestic, foreign, and multinational corporations, whose shares of soybeans are 42.75, 14.90 and $42.35 \%$, respectively. Moreover, considering that Wehrtec - Agricultural Technology Ltd. was acquired by Bayer, the percentage of GM soybean varieties belonging to multinational companies rose to $46.67 \%$. For cotton, $26.67 \%$ of the protections belong to EMBRAPA (a public institution), and $73.33 \%$ belong to private companies (Figure 1).

Public institutions maintaining GM soybean varieties and their respective numbers of protections are as follows: Agência Goiana de Desenvolvimento Rural e Fundiário (AGENCIARURAL) (2), Secretaria de Agricultura Pecuária e Abastecimento do Estado de Goiás (SEAGRO) (2), Fundação Estadual de Pesquisa Agropecuária do Rio Grande do Sul (FEPAGRO) (2), Universidade Federal de Viçosa (UFV) (5), Empresa Brasileira 
de Pesquisa Agropecuária (EMBRAPA) (37), EMBRAPA in partnership with Empresa de Pesquisa Agropecuária de Minas Gerais (EPAMIG) (5), EMBRAPA in partnership with SEAGRO (3), EMBRAPA in partnership with AGENCIARURAL (1), and EMBRAPA with Empresa de Assistência Técnica, Extensão Rural e Pesquisa Agropecuária do Estado de Goiás (EMATER) (1). These 58 protections correspond to $18.53 \%$ of the total number of protections.

The domestic private companies include the Cooperativa Central de Pesquisa Agrícola (COODETEC) (30), FTS Sementes S.A. (24), Cooperativa Central Gaúcha Ltda (CCGL Technologia) (15), Wehrtec Agricultural Technology Ltd. (11), Instituto Mato Grossense do Algodão (IMAMT) (3), Tropical Melhoramento e Genética Ltda (TMG) (5), Fundação de Apoio à Pesquisa Agropecuária de Mato Grosso (Fundação MT) in partnership with Unisoja S.A. and TMG (17), GDM Genetics of Brazil Ltd. (2), and finally, two individuals named Luiz Alberto Benso (1) and Vendruscolo Juarez (1). These companies and individuals represent 109 protections and $34.82 \%$ of the total.

Foreign private companies include Anglo Netherlands Grains B.V. (5), Don Mario Associates S.A. (16) and Granar S.A. (17). The multinational companies include Monsoy (54), Nidera S.A. (23), DuPont Brazil - Pioneer Seed Division (15), Syngenta Seeds Ltd. (13), and Bayer (3). In total, there are 108 (34.50\%) protections from multinational companies; combined with the foreign companies, the total comes to 146 varieties from other countries, representing $46.65 \%$ of the varieties.

Four cotton varieties were protected by EMBRAPA, and these were developed by a domestic private company (IMAMT); the remaining 10 were developed by Delta \& Pine Land Technology Holding Company, which is owned by Monsanto (Figure 1).

Figure 2 shows the current number of protections of conventional and GM varieties developed from 1998 to 2013. The growth in the number of GM soybean protections in recent years is evident. Since 2006, there have been more protections for transgenic than conventional soybean varieties. In addition to the strong growth of transgenics, the number of non-transgenic varieties is decreasing. This situation indicates the replacement of conventional varieties by GM varieties, especially in 2013. There has been a change in the number of protected GM cotton varieties over the years, with more GM varieties than the conventional between 2007 and 2010 .

\section{Registrations}

There are currently 783 varieties of GM corn registered with MAPA, all of which were developed by private companies. Of these GM varieties, $98.85 \%$ belong to multinational companies, and the remainder belong to COODETEC and Geneze Sementes S/A. There are 582 registered GM soybean varieties; $500(85.91 \%)$ of them were produced by private companies, and $82(14.09 \%)$ were developed by public institutions. Within the subdivisions of domestic and multinational private companies, in this case, all foreign companies were multinational (Figure 3). It appears that $43.60 \%$ of the GM soybean registrations belong to multinational companies, and $56.40 \%$ belong to domestic companies.

There are 30 registered GM cotton varieties, and $86.67 \%$ of them were developed by private institutions (Figure 3). Only four cotton varieties were developed by national 

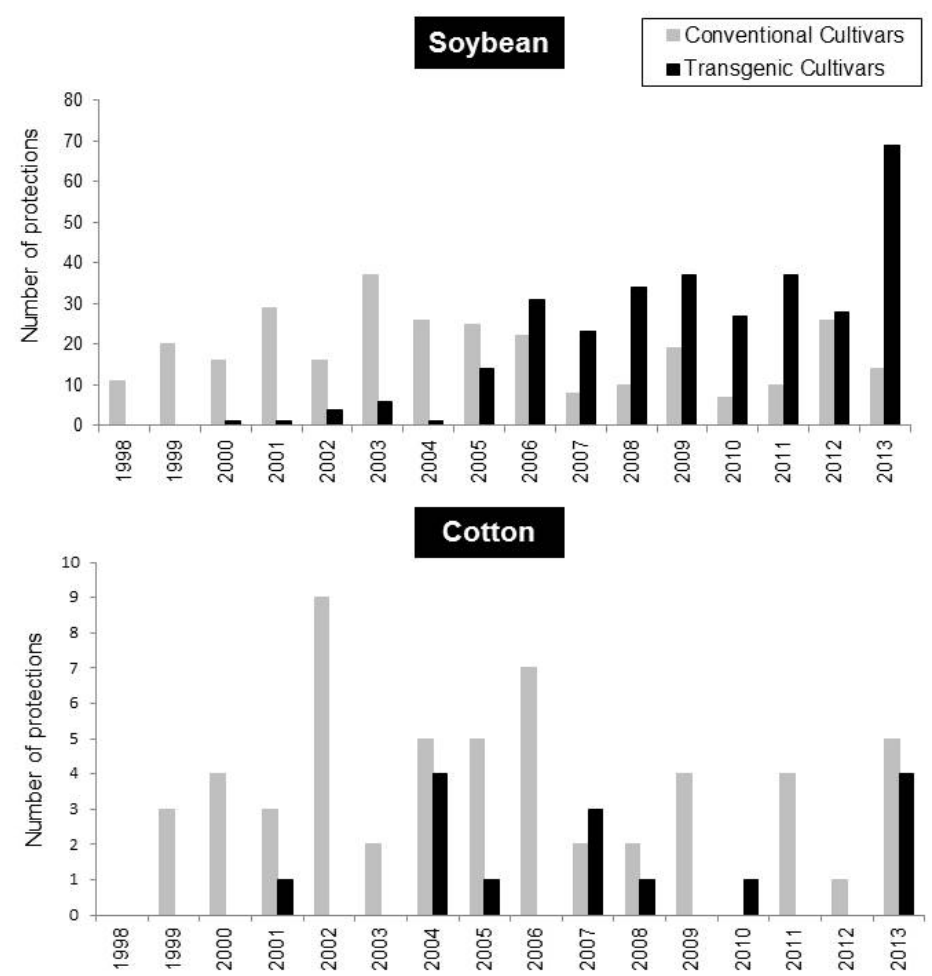

Figure 2. Number of current protections for conventional and GM crops developed between 1998 and 2013.

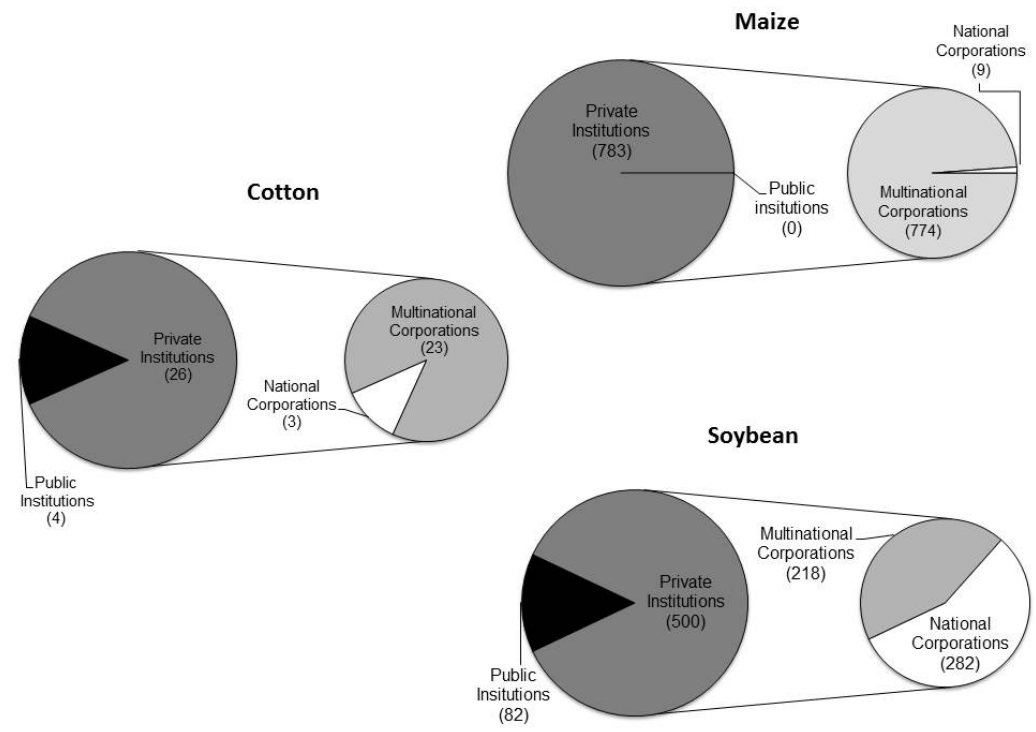

Figure 3. Number of registered GM soybean, cotton and corn crops according to the nature of the responsible institutions. 
institutions, which represent $13.33 \%$ of the registered varieties.

Private companies responsible for GM corn include DuPont Brazil S/A - Pioneer Seed Division (307), Monsanto Brazil Ltd. (295), Dow AgroScience Brazil Seeds \& Biotech Ltd (99), Syngenta Seeds Ltd. (62), COODETEC (8), Nidera (11) and Geneze Seeds S/A (1). Therefore, only seven companies are responsible for all GM corn varieties registered in Brazil. In addition, DuPont owns 39.21\% of these corn registrations, and Monsanto owns $37.68 \%$. Therefore, only two companies own nearly $80 \%$ of the registrations released for the sale of seed for this crop.

For soybeans, the multinational companies are Monsoy (89), Nidera (48), Syngenta (41), DuPont (30) and Bayer (10), totaling 218 (37.46\%) of the registered varieties (Figure 3).

National private institutions responsible for registered GM soybean include GDM Genetics of Brazil Ltd (64), COODETEC (54), FTS Seeds S/A (34), Mato Grosso Agricultural Research Foundation (Fundação MT) in partnership with Unisoja S.A. and TMG (23), Gaucha Central Cooperative Ltd. (22), Wehrtec - Agricultural Technology Ltd. (18), BR Genetics Inc. (15), Tropical Breeding and Genetics Ltd. (Tropical Melhoramento e Genética Ltda. - TMG) (13), Fundação MT and Unisoja S/A (9), Caraíba Genetics Ltd. (8), Unisoja S/A (6), Geneze Seeds S/A (6), Integrated Educational Centre - (Centro Educacional Integrado - CIS) (4), two individuals named Edeltraut Erica Strobel (3) and Luiz Alberto Benso (2), and finally, Agro North Research and Seeds Ltd. (1). These institutions represent 282 registered varieties $(48.45 \%$ of the total).

The public institutions responsible for registered GM soybean include EMBRAPA (53), EMBRAPA and EPAMIG (8), EMBRAPA and GO EMATER (7), UFV (5), AGENCIARURAL (3), FEPAGRO (2), SEAGRO (1), EMBRAPA and SEAGRO (2) and EMBRAPA and AGENCIARURAL (1). A distinction should be made for EMBRAPA, which is the public agency with the greatest number of records for GM soybeans and is responsible for $9.11 \%$ of all registrations.

For cotton farming, 17 varieties (56.67\%) are owned by D\&PL Brazil Ltd., which is owned by Monsanto. Bayer has five (16.67\%), EMBRAPA has four (13.33\%), Mato Grosso Cotton Institute holds three (10\%) and Dow Agroscience has a single (3.33\%) registered variety. Therefore, $76.67 \%$ of the registered GM cotton varieties are the responsibility of multinational companies, and Monsanto alone owns $56.67 \%$ of them.

According to Figure 4, which shows the number of registered GM varieties compared to conventional varieties from 1998 to 2013, corn had strong growth, which was even greater because it was released in 2007. In 2008, the number of GM corn varieties was already greater than that of conventional varieties, reaching a difference of 83 more transgenic varieties in 2009. For soybean farming, there was a similar trend; however, the GM varieties have outpaced conventional varieties since 2006, especially in 2012, when the difference intensified greatly (123 cultivars). Therefore, like protections, the number of registered transgenic soybeans is growing and surpassing that of conventional varieties. Moreover, the number of non-transgenic varieties is decreasing, suggesting the replacement of conventional forms by GM varieties. For cotton, in the years 2009, 2010, 2012 and 2013, the number of registered GM varieties was greater than that of conventional varieties. 
Soybean

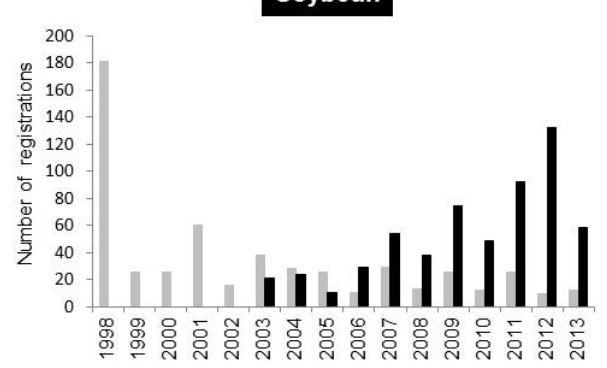

Maize

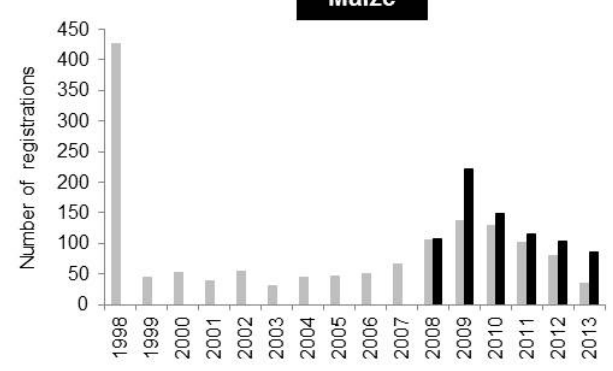

Cotton

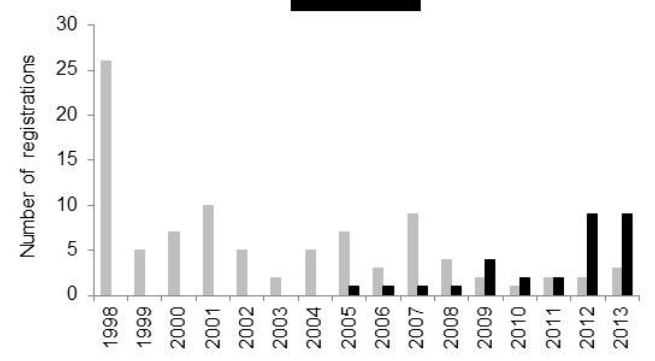

Figure 4. Number of conventional and GM crops developed between 1998 and 2013.

\section{DISCUSSION}

The present study revealed that the market for genetic engineering is restricted almost exclusively to private companies because EMBRAPA is the only national representative that has developed two events. Additionally, one of those events is not exclusive to EMBRAPA because the technology was obtained in partnership with BASF. All other GM varieties are the property of only five multinational companies, especially Monsanto, which alone owns $41.67 \%$ of the commercially released events.

Considering the existing transgenic cultivars certified by MAPA and the events used to develop them, $73.05 \%$ of the technologies used belong to Monsanto. Monsanto is followed by the partnership between DuPont and Dow AgroScience, which owns 16.34\% of the technologies used, and Syngenta with $4.37 \%$. Considering these four multinational companies and the partnerships between them, Table 4 shows that they own $99.42 \%$ of the technologies adopted to obtain the existing transgenics approved by MAPA. Moreover, there is a large gap between Monsanto and the other companies, confirming the degree of dominance by this company in this area (Table 4).

Therefore, for all three crops (corn, soybeans, and cotton), Monsanto is the leading (Table 3). Among all soybean cultivars certified, $99.48 \%$ were developed by techniques patented by Monsanto, as were $53.26 \%$ of corn cultivars and $76.67 \%$ of cotton cultivars. In addition to owning most of the transformation events released for sale (41.67\%), this company also achieves the greatest amount of technological adoption for the development of transgenics (73.05\%). Moreover, the present study also shows that, of all transgenic cultivars approved by MAPA, $57.13 \%$ are tolerant to glyphosate, the main ingredient of the herbicide Roundup, 
which is owned by Monsanto. Given the inescapable link between the acquisition of transgenic seed and the purchase of the herbicide to which the plant is tolerant, Monsanto also dominates the supply of herbicides used on transgenic crops. This situation further alienates producers who practice family farming from the possibility of acquiring seed at consistent prices, burdening this sector of the GM agriculture market. Indeed, the prospect is that family farming will be weakened by the growth of transgenics in the seed market.

With respect to the institutions responsible for the development of cultivars certified by MAPA, it is important to note that EMBRAPA (with partnerships) is responsible for 46 of the 58 soybean varieties protected by public institutions, which amounts to $79.31 \%$ of such protections. The private domestic company with the greatest percentage of protections is COODETEC with $9.58 \%$ of the protections. Therefore, multinational companies are leading in protections of transgenic soybean varieties, mainly due to the activity of Monsanto.

In cotton farming, the trend is similar, and $76.33 \%$ of all protected varieties were developed by the private sector, with the majority of the market share $(70 \%)$ being developed by D\&PL Brazil Ltd. (Monsanto). EMBRAPA is responsible for the remainder of the varieties developed by public institutions (26.67\%) (Figure 1).

For the genotypes registered with MAPA, only five multinational corporations own $98.85 \%$ of all (783) registered corn varieties. Approximately $80 \%$ of these genotypes belong to DuPont (39.21\%) and Monsanto (37.68\%) (Figure 3).

Of the 582 registered transgenic soybeans, $85.91 \%$ were developed by private institutions, with multinational companies responsible for $37.46 \%$, domestic companies responsible for $48.45 \%$ and public institutions responsible for $14.9 \%$. The stand-outs are Monsanto with 15.29\%, GDM Genetics of Brazil Ltd. with 11\%, COODETEC with 9.28\% and EMBRAPA with $9.11 \%$ of registered GM soybeans. Thus, there is greater competition by domestic companies in terms of the number of registrations for this crop; however, Monsanto remains the largest owner (Figure 3).

As for the number of cotton registrations, 17 belong to a subsidiary of Monsanto (D\&PL). Bayer, EMBRAPA, the Mato Grosso Cotton Institute and Dow Agroscience own, respectively, five, four, three and one variety each. Therefore, $76.67 \%$ of the GM cotton varieties are owned by three multinational companies (Figure 3).

We also investigated the number of protected transgenic cultivars relative to conventional cultivars and concluded that the number of transgenic soybean cultivars has been higher than that of conventional cultivars since 2006. In addition to such strong growth, the number of non-transgenic varieties is decreasing, demonstrating the replacement of conventional crops by GM crops. Cotton shows the greatest fluctuation in the number of GM crop protections, with high numbers in 2007 and 2010 (Figure 2).

The ratio between registered transgenic and non-transgenic cultivars confirms that conventional seeds are being replaced. GM corn was first registered in 2008, and since then, it has outnumbered conventional crops. For soybeans, the number of registered transgenic crops has been increasing since 2006, while that of conventional crops has oscillated with a tendency toward a decrease. The number of GM cotton crops in the last five years was also greater than or equal to the number of conventional crops (Figure 4).

Combining these facts with the adoption rate of transgenics by farmers, which according to estimates, will be approximately $92.4 \%$ for soybeans, $81.4 \%$ for corn and $47.0 \%$ for cotton in 2013/2014 (Céleres, 2013), it is possible to predict an intense replacement of conventional crops by GM crops for soybeans, corn and cotton (the last to a lesser extent). This situa- 
tion is even more serious because, according to the Mato Grasso Association of Soybean Producers (Associação dos Produtores de Soja do Estado de Mato Grasso - APROSOJA) and the Brazilian Association of Non-Genetically Modified Grain Producers (Associação Brasileira de Produtores de Grãos Não Geneticamente Modificados - ABRANGE), Monsanto is restricting farmers' access to conventional (non-GM) soybean seeds by imposing sales quotas on seed distributors, requiring them to sell $85 \%$ transgenic RR soybean seed and no more than $15 \%$ non-transgenic soybean seeds (Macedo, 2010).

This situation can be attributed more to the "lobby" of multinational companies than to technological advantages (Nature, 2010), due to the pressure of contracts imposed on producers, whom the law does not protect. Thus, farmers are at the mercy of contamination by the application of herbicides to neighboring GM crops, non-compliance with labeling standards and non-payment of premiums for GM-free farming. In agreement with Pessanha and Wilkinson (2006) and Mechlem (2010), there is considerable difficulty in maintaining conventional crops in areas where there are GM crops. This difficulty causes farmers and society to increasingly depend on patented seeds from multinational companies, who can set prices and control the global food market because soybeans and corn are critical for food production. They are present in animal feed, vegetable oils and countless processed products. Together, these crops produce approximately $80 \%$ of the grains in Brazil.

Moreover, as legislation does not establish a maximum price for the collection of royalties, and because the market is largely controlled by a few companies, farmers are exposed to the business strategies of this oligopoly, leaving them without choice and practically obligated to pay the prices set by the multinational companies.

Thus, it is concluded that the rapid advance of biotechnology companies is worrisome. The supply of transgenic seeds by these companies is a monopoly protected by the law, such that producers are left with no option, resulting in the rapid replacement of conventional crops by GM crops. In addition to being expensive, this strategy excludes small farmers because they cannot save seeds for later use. This situation concentrates production within large domestic agribusiness companies.

\section{ACKNOWLEDGMENTS}

Research supported by the Fundação de Amparo à Pesquisa do Estado do Rio de Janeiro (FAPERJ) and Conselho Nacional de Desenvolvimento Científico e Tecnológico (CNPq).

\section{REFERENCES}

Araújo JC (2010). A Lei de Proteção de Cultivares: Análise de Sua Formulação e Conteúdo. 1st edn. Edições Câmara, Brasília.

Brasil (1997). Lei 9.456, de 25 de abril de 1997. Institui a Lei de Proteção de Cultivares e dá Outras Providências. Available at [http://www4.planalto.gov.br/legislacao/legislacao-1/leis-ordinarias/1997\#content]. Accessed October 17, 2013.

Brasil (2005). Lei 11.105/05, de 24 de Março de 2005. Estabelece Normas de Segurança e Mecanismos de Fiscalização de Atividades que Envolvam Organismos Geneticamente Modificados - OGM e Seus Derivados, Cria o Conselho Nacional de Biossegurança - CNBS, Reestrutura a Comissão Técnica Nacional de Biossegurança - CTNBio, Dispõe Sobre a Política Nacional de Biossegurança - PNB e dá Outras Providências. Available at [http://www4.planalto.gov. br/legislacao/legislacao-1/leis-ordinarias/2005\#content]. Accessed October 17, 2013.

Brookes G and Barfoot P (2010). GM crops: Global Socio-Economic and Environmental Impacts 1996-2008. PG Economics Ltd, Dorchester. 
Carvalho SIC, Bianchetti LB and Reifschneider FJB (2009). Registro e proteção de cultivares pelo setor público: a experiência do programa de melhoramento de Capsicum da Embrapa Hortaliças. Hort. Bras. 27: 135-138.

Céleres (2013). Relatório Sobre Biotecnologia: $1^{\circ}$ Acompanhamento de Adoção da Biotecnologia Agrícola no Brasil, Safra 2013/14. Available at [http://celeres.com.br/wordpress/wp-content/uploads/2013/08/IB13011.pdf]. Accessed October 15, 2013.

CTNBio (2013). Comissão Técnica Nacional de Biossegurança. Aprovações Comerciais. Available at [http://www.ctnbio. gov.br/]. Accessed August 01, 2013.

James C (2009). Global Status of Commercialized Biotech/GM Crops: 2009. ISAAA Brief n. 41. ISAAA: Ithaca.

James C (2011). Global Status of Commercialized Biotech/GM Crops: 2011. ISAAA Brief n. 43. ISAAA: Ithaca.

James C (2012). Global Status of Commercialized Biotech/GM Crops: 2012. ISAAA Brief n. 44. ISAAA: Ithaca.

Macedo D (2010). Farmers Complain that Monsanto Restricts Access to Conventional Soybean Seeds. Agência Brasil, 18 de Maio. Available at [http://www.gmwatch.org/index.php?option=com_content\&view=article\&id=12237]. Accessed October 17, 2013.

Marinho CD, Martins FJ, Amaral SC, Amaral Junior AT, et al. (2011). Revisiting the Brazilian scenario of registry and protection of cultivars: an analysis of the period from 1998 to 2010, its dynamics and legal observations. Genet. Mol. Res. 10: 792-809.

Mechlem K (2010). Agricultural biotechnologies, transgenic crops and the poor: opportunities and challenges. Hum. Right Law Rev. 10: 749-764.

Munro A (2003). Monopolization and the regulation of genetically modified crops: an economic model. Environ. Dev. Econ. 8: 167-186.

Nature (2010). How to feed a hungry world. Nature 466: 531-532.

Pessanha L and Wilkinson J (2006). Impactos Socio-Econômicos e Políticos da Expansão do Cultivo da Soja Transgênica Sobre os Agricultores na América Latina. VII Congresso Latinoamericano de Sociología Rural, Quito.

Potrykus I (2010). Regulation must be revolutionized. Nature 466: 561.

Teramoto JRS and Teixeira JV (2008). Propriedade Intelectual e Proteção de Cultivares. Série Tecnológica APTA, Manual Técnico DGE, Campinas. 